\title{
THE ROLE OF THE SELF-GOVERNING REGIONS IN CORONAVIRUS CRISIS IN SLOVAKIA
}

\begin{abstract}
The coronavirus crisis is a major social issue addressed in many countries over the last two years. Everyday life has been significantly influenced by the measures taken in an effort to eliminate the effects of this virus. The representatives of the state were not prepared for such a situation, which was reflected in the differently chosen strategies in the member states of the European Union. If we take a closer look at the situation in Slovakia, the outbreak of the corona crisis was associated with the parliamentary elections and change of government at the end of February 2020. Political aspects significantly influenced the initial phase of the fight against Covid-19. Self-governing regions were active in the individual stages and became important actors in the whole process. The article focuses on the evaluation of the role of two selected regional units - Bratislava and Košice self-governing regions within the coronavirus crisis. We primarily focus on the taken measures at the beginning of the whole process, when regional governments reacted sooner than the state itself. In addition, we analyse how self-governing regions have been involved in the vaccination process. In this context, we evaluate the current state and number of vaccinated people in both municipalities.
\end{abstract}

Key words: self-governing regions, competencies, coronavirus crisis

\section{INTRODUCTION}

The political and social situation in Slovakia is currently affected by the ongoing corona crisis. We can definitely identify it as a global problem that has affected almost the whole world since the beginning of 2020. Due to the absence of a coherent strategy within the European Union, individual Member States have opted for a specific system of measures to prevent the spread of the virus. According to statistical indicators, in the case of Slovakia there is a significant disparity in the number of infected and dead between the first and second wave in comparison with other countries. Paradoxically, managing the first wave was more successful

1 PhDr. Dalibor Mikuš, PhD. Department of Public Administration Faculty of Social Sciences University of Ss.Cyril and Methodius in Trnava, Trnava, Slovakia. Email: dalibor.mikus@ucm.sk 
than managing the second wave. However, the outbreak of the corona crisis itself was associated with the change of government after the parliamentary elections. In that period the self-governing regions presented themselves as active players and largely replacing the role of the state. The Bratislava self-governing region was the first to adopt a set of measures immediately after there was confirmed the first infected case in Slovakia. The primary goal of the article is to evaluate the role of self-governing regions in the corona crisis in terms of implemented measures. In the first part we define the competencies and powers of regional units. Based on this, we identify the tools that regional governments could use in resolving the crisis. The second chapter of this article focuses on specific evaluations in terms of implemented measures and their consequences, but also the role of the regional governments in the vaccination process. We also draw information from interviews with representatives of selected self-governing regions, which were carried out in electronic form

\section{COMPETENCE FRAMEWORK OF SELF-GOVERNING REGIONS}

Regional self-governing units are often considered to be a unit with limited competencies by the professional public. Political parties open a debate on the position of these units in the structure of self-government after each regional election. On the one hand, we identify statements in favour of reforming the current system in terms of strengthening competencies. On the other hand, some political parties are pushing for the abolition of the entire level of regional self-government. According to these views, the competencies should be divided between the local governments and the state. Despite this fact, self-governing regions have various competencies that can really affect the creation of public policy (Švikruha, 2018). The transfer of competences itself was a long-term process that needs to be placed in the broader framework of regional self-government. Political aspects play a decisive role in individual phases and are directly signed under the applied model (Gurńák, 2014). Only on the basis of the evaluation of the whole process of creating regional self-government is possible to understand applied model of the competence framework.

The issue of competencies was accompanied by expert discussions on the model of regional self-government since 1989. Regarding the adoption of the reform of the territorial division of Slovakia, the representatives of the Association of Towns and Municipalities in Slovakia (ZMOS) emphasized the fact that it is primarily necessary to address the powers of the created units and not their number. In this case, they clearly advocated the sequence of steps taken - decentralization of competencies, decentralization of finances and political decentralization. Otherwise, regional units without real content would be created (Nižňanský, 
Hamalová, 2013). However, the government of Vladimír Mečiar was in power in 1996 and centralized model was promoted. In practice, she could not relinquish power, so she emphasized the reform in two phases. Firstly, a system of division of state administration through the renewal of regions should have been created. Self-governing system was planned in the second step (Kováčová, 2014). Based on the Act no. 221/1996 Coll. on the territorial and administrative organisation of the Slovak Republic and Act no. 222/1996 Coll. on the organization of local state administration thus were established eight regional units. However, a fullfledged self-government was not put in practice as only the deconcentrated state administration bodies were created (Csachová, 2010). Therefore, no competencies were automatically transferred to the level of created units. We can objectively say that centralist tendencies persisted at the regional level. It means there was no political will to apply self-governing mechanisms.

The 1998 parliamentary elections became a decisive milestone in terms of the creation of regional self-government. The governing coalition led by Mikulás Dzurinda advocated a decentralized model. According to Klimovský, selfgoverning units should have represented important tools also in terms of drawing European funds (Klimovský, 2014). There is an important fact that Slovakia opened negotiations on accession to the European Union. Viktor Nižňanský as the government delegate for reform of public administration set out the reform on three levels. Decentralization of competencies should have been the basis of the new system. In practice, it was implemented only after the adoption of territory arrangement, which became the subject of political disputes (Kováčová, 2015). The ruling coalition was formed by political parties with different ideological orientations. According to Nižňanský (2005), finding a consensus was very difficult and this was reflected in long negotiations. Finally, the government approved the model of 12 self-governing regions as a compromise solution. The originally proposed historical variant of 16 units had been applied in the territory of Slovakia during the existence of the Kingdom of Hungary but it was not accepted (Gurńák, 2014). At the same time, the ministers for the Democratic Left Party (SDL) withdrew from the proposal of 8 self-governing units. However, the vote in Parliament produced a different result. The amendments of the deputies of the Movement for Democratic Slovakia (HZDS) were reflected in the modification of the model to 8 units. Adopted Act no. 302/2001 Coll. On the self-government of self-governing units defined a different model in comparison with the government proposal. This fact was reflected in the government crisis, because the Hungarian Coalition Party (SMK) wanted to leave the ruling coalition (Mikuš, 2018).

The issue of competencies of self-governing units became the subject of negotiations of the National Council of the Slovak Republic only after the adoption of the principles of political decentralization. Tensions in the governing coalition were compounded by the fact that the proposed government model 
was accepted within the competence framework. We can identify an important political aspect. Hungarian Coalition Party (SMK) was a condition to adopt the original model. Otherwise, the political party would leave the governing coalition (Machyniak, 2018). The legislative process was completed with the adoption of Act no. 416/2001 Coll. on the transfer of certain powers from state administration bodies to municipalities and self-governing regions. The process of creating regional self-government was completed though it was influenced by a wide range of political aspects (Sloboda, 2014). Self-governing units acquired their own package of competencies. Therefore, the principle of decentralization was automatically put in practice.

The scope of competence clearly defines the role and importance of self-governing regions. The establishment of regional self-government enabled the transfer of another package of competencies to municipalities as a selfgoverning unit created in 1990. As for regional self-government, the transfer of competencies was carried out in the period from April 1, 2002 to January 1, 2004. The whole process was divided into 4 phases with goal to ensure the sequence of implemented steps (Nižnanský, Hamalová, 2013). The most important powers can be identified in the areas of transport, education, health, culture and social affairs. In the field of transport, it is ground communications and roads of 2 nd and 3rd class together with the licensing of regular suburban bus services. In practice, the regulation of prices and graduating individual discounts are parts of the competence framework. At the same time, the citizen has the right to file complaints regarding problems with winter road maintenance management to the relevant administrative authorities established by the self-governing region. In the field of education, competencies are linked to secondary schools such as vocational schools, centers of training education, educational institutions except language schools founded by primary schools, primary art schools, boarding houses, institutions providing school catering, training education or centers of school services (Kováčová, 2014). Camps in nature have a specific position. School directors are directly appointed or designated as the self-governing region acts as the founder. In the field of healthcare, region is also the founder of health centers, hospitals, ambulances and pharmacies (Adamcová, 2011). In practice, it has the right to set office hours. In addition, the self-governing region has the power to suspend the activities of medical facilities by an adopted regulation. A citizen has the right to file a complaint with an outpatient clinic if unjustified fees for services performed have been received. The provision of social services is carried out through social service homes, while self-governing region decides on the amount of prices or control of the services provided. If we look at the budgets of self-governing regions, more and more funds are being invested in this area (Kováčová, 2014). Within culture, it is primarily the management of theatres, galleries, museums and libraries. Open-air museums and educational centers have 
a specific position.

We consider cross-border cooperation to be an important element in the development of self-governing regions, which is developing significantly in the areas of tourism, innovation and cooperation between educational institutions. It is implemented mainly within the framework of the European Union program called Interreg A supporting cooperation between NUTS III regions. The condition of cooperation is at least $t$ neighbouring states of the European Union. This initiative was created in 1990 by defining cross-border cooperation as an official objective of European cohesion policy. According to statistics, more than $37.5 \%$ of the European Union's population lives in border territories. Therefore, the potential of border regions is necessary to exploit (Interreg A - Crossborder cooperation, 2021). In terms of the geographical location of individual self-governing regions in Slovakia, each self-governing unit has borders with a different state. On this basis, cross-border cooperation is an important tool for socio-economic development. The opportunity of drawing financial resources from European funds is one of the important attributes of balancing disparities within the regions of the European Union. By summarizing the individual competencies, we can objectively declare that self-governing regions have relatively broad powers. Following the outbreak of the corona crisis, these units became important actors in the process of adopting the necessary restrictive measures.

\section{THE CORONAVIRUS CRISIS AND THE ROLE OF SELECTED SELF-GOVERNING REGIONS}

Covid-19 has affected almost all areas of social life. It was automatically reflected in the introduction of several measures to eliminate the effects of this virus. A global crisis has broken out with huge implications for the daily lives of citizens. The first signs of danger appeared at the turn of February and March 2020, when there were the first cases in several European countries. However, the primary topic in Slovakia during this period was the parliamentary elections held at the end of February. The competition of political parties for a share in state power thus largely covered the issue of Covid-19. The result of the parliamentary elections was clearly determined by the end of the government of Peter Pellegrini and the victory of the opposition political parties under leadership of Igor Matovič (Havlík et al., 2020). Therefore, Slovakia was affected by the coronavirus crisis during the period of the exchange of two governments. In this context, we focus on the importance of self-governing regions playing important role in the first phase of the fight against Covid-19. We evaluate two specific cases - Bratislava and Košice self-government regions. These two territorial units were able to implement measures at an early stage. However, evaluations need to be placed in the context of national developments. 
Covid-19 has been connecting with Slovakia since the confirmation of the first infected man on March 6. At that time, Prime Minister Peter Pellegrini was in office though his party SMER-SD lost the parliamentary election. The original government solved the challenges that arose because the formation of a new government coalition took some time. In this context, the role of regional units needs to be emphasized. The Bratislava self-government region was the first to introduce measures on March 8. They concerned areas where the self-government unit acted as the founder and had specific powers. Education was an important area that needed to be addressed. Based on the decision of the authorities, schools had been closed from March 9 until March 13. At the same time, students were forced to leave the dormitories. The measures concerned 54 secondary schools such as grammar schools, vocational schools, or conservatories (Bratislava secondary school closed over Covid-19 suspicion, 2020). The Bratislava selfgovernment region took responsibility and become an example for the state power. The same procedure was applied by the representatives of the Košice selfgovernment region, where 70 secondary schools and school facilities were closed from March 11. In response to this step, the universities opened the question about interrupting the face-to-face education. Rectors and crisis staffs introduced distance education at the largest university in Slovakia - Comenius University in Bratislava. Subsequently, other universities joined this statement such as the Slovak University of Technology, University of Economics or Slovak Medical University. The pressure put on the government was reflected in the adoption of comprehensive measures. A state of emergency was declared by a government resolution No 114 on March 16. The government has the power to declare it in accordance with the Constitutional Act No 227/2002 on state security in times of war, hostilities, exceptional circumstances and emergency. Based on that legislation, the state can restrict fundamental rights and freedoms and to impose obligations within the scope and time period strictly necessary. The act sets a maximum length for no longer than 90 days (States of emergency in response to the coronavirus crisis, 2020). At the same time, the Ministry of Education decided to stop face-to-face education at all types of schools for 14 days. Depending on the deteriorating pandemic situation, secondary school students did not return to school until June 22 . However, the teaching process was only voluntary as it took place the last week before the summer holidays. The acceptance of the state of emergency at the beginning of October was also reflected in the resumption of face-to-face education on October 12. The central government-controlled measures adopted in the second wave of the coronavirus crisis.

At the beginning of the pandemic, the Bratislava self-governing region also took measures in other areas. In comparison with the public authorities, it was applied earlier. Any visits to social services facilities have been banned since March 9. The self-governing region wanted to eliminate the possibility of spreading 
the disease among the most vulnerable group of the population. The Košice selfgoverning region together with other self-governing units joined this step as well. At the same time, the supply of hygiene and disinfectants was strengthened though the Administration of State Material Reserves at the national level was not prepared at all. There even appeared corruption cases linked to the head of this body. Subsequently, he was removed from office. In the area of transport, selfgoverning regions operate means of regional transport. Both selected regional units concerned emphasized the disinfection of vehicles. In addition, the number of regular lines has been reduced in an effort to ensure consistent compliance with hygiene standards (Konečný-Brídziková-Senko, 2021). In the field of culture, it was decided to close all premises founded by the regional self-government such as museums, galleries, theaters or libraries. As for the planned cultural events, the self-governing authorities demanded their cancellation.

We also identify the role of self-governing units in the second wave of coronavirus in connection with vaccination. Although the whole process was launched on December 26, 2020, neither the state nor the hospitals had the space and personnel capacity to handle it. The establishment of vaccination centers has become one of the most important tasks. In cooperation with central state administration authorities and the National Health Information Center(NCZI) were established many of them. Regarding the Bratislava self-governing region, a pilot vaccination center was created at the health center in Karlova Ves on February 27, 2021. The first doses were given exclusively to teachers and employees of critical infrastructure. Subsequently, the representatives of the region proceeded to create a large capacity center at the National Football Stadium. The primary objective was to increase the vaccination of the adult population with a daily maximum of 2500 people. From the beginning of vaccination on March 13, the highest number of people among vaccination centers in Slovakia has been vaccinated there so far. In early May, a vaccination center was also set up in Pezinok on the premises of the local health center. The aim is to improve accessibility for people from the "Malokarpatsko" region. In terms of the geographical balance of the centers, a vaccination center was also established in the town of Malacky. Residents of the "Záhorie" region thus also have the opportunity to use the services without excessive travel. As for the Košice self-government region, vaccination centers have also been set up since the end of February. The geographical diversity of the region is a specific feature in comparison with the Bratislava self-government region. While the first large capacity center was opened on February 27 in the premises of a vocational school in Košice, the second has already been set up in Michalovee for better accessibility to the border territories. It was necessary to open a vaccination center in the remote western part of the region. Based on this, a large capacity center was established in Spišská Nová Ves. The Košice self-government region is characterized by a high population of Roma living in 
closed communities. The mobile vaccination service plays an important role in the vaccination of marginalized communities. Vaccine doses are thus offered directly in the field. This service is also necessary for vaccinating clients in social service homes for adults.

Table 1 Vaccinated people according to self-governing regions

\begin{tabular}{|l|l|l|}
\hline & $\begin{array}{l}\text { Number of vaccinated } \\
\text { with the first dose }\end{array}$ & $\begin{array}{l}\text { Number of vaccinated } \\
\text { with the second dose }\end{array}$ \\
\hline Bratislava region & 758941 & 597270 \\
\hline Košice region & 547953 & 450695 \\
\hline Banská Bystrica region & 452895 & 333671 \\
\hline Nitra region & 502321 & 381454 \\
\hline Prešov region & 558507 & 451788 \\
\hline Trenčín region & 404817 & 451788 \\
\hline Trnava region & 519411 & 352502 \\
\hline Žilina region & 488586 & 364913 \\
\hline
\end{tabular}

Source: Coronavirus and Slovakia, 2021.

The Bratislava self-governing region has currently the highest number of vaccinated inhabitants with the first and second dose. Based on this fact, the head of the self-governing region Juraj Droba and the mayor of the capital Matúš Vallo asked the Ministry of Health for more vaccines to Bratislava from other parts of Slovakia. However, the proposal was rejected in terms of maintaining balance among regions. As for individual districts of the Bratislava self-governemnt region, there have currently been more than $55 \%$. This figure is one of the highest within capitals in member states of the European Union. Although it is only $39 \%$ in the district of Malacky, overall, the region shows above-average values.

Graph 1 Percentage of vaccinated population in districts of the Bratislava selfgoverning region

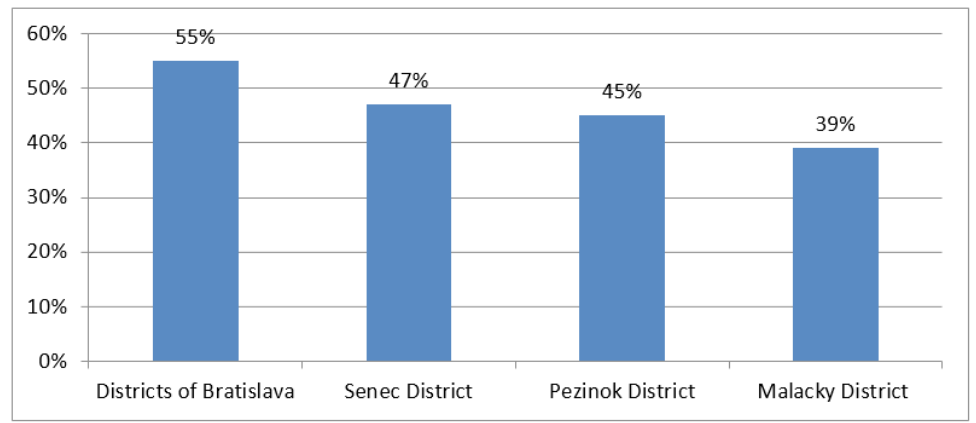

Source: Coronavirus and Slovakia, 2021. 
In the case of the Košice self-governing region, the percentage is significantly lower. On the one hand there are the districts of Košice with more than $40 \%$ of the vaccinated population. On the other hand the district of Gelnica only with $24 \%$. Compared to other districts, this is the lowest percentage in Slovakia at all.

Graph 2 Percentage of vaccinated population in districts of the Košice selfgoverning region

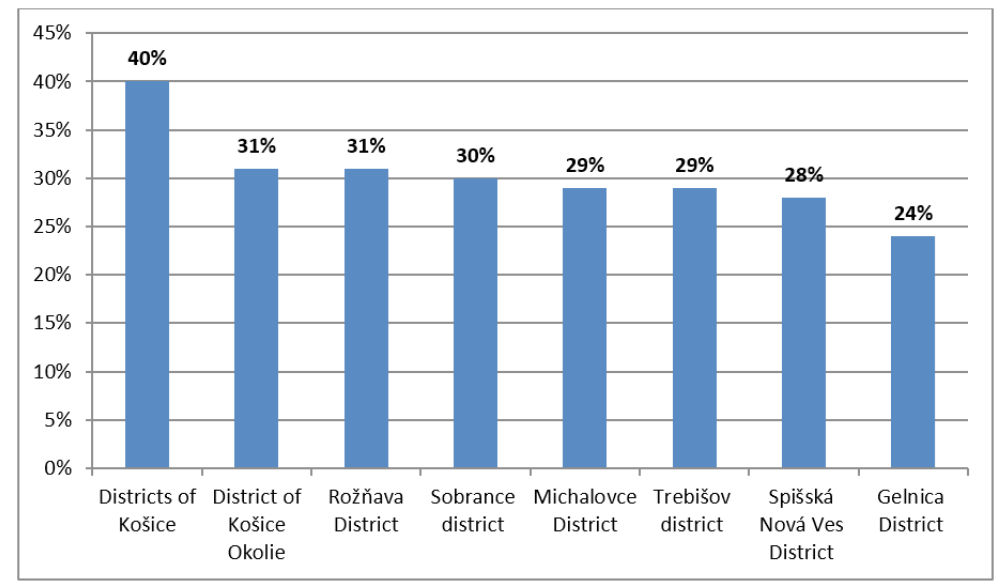

Source: Coronavirus and Slovakia, 2021.

In addition, we have identified that political parties play an important role in citizens' decision-making. The People's Party of our Slovakia (LSNS) has rejected vaccination against Covid-19 for a long time and directly influences its voters. If we look at the districts within the Košice self-governing region with the lowest percentage of vaccinated people, it was L'SNS that received above-average support there. As an example, we can mention the district of Gelnica, where the percentage of vaccinated is the lowest. Although the political party gained $6.8 \%$ in parliamentary elections in Slovakia, it was $14.5 \%$ in the selected district. On the contrary, the support of LSNS was only $5.5 \%$ in the districts of Košice with the highest rate of vaccinated people. We identify the same fact in the Bratislava selfgoverning region where the percentage of vaccinated is the highest in Slovakia. As we have emphasized above, the districts of Bratislava reach more than 55\%. Support for LSNS was the lowest there in Slovakia. According to the results of the 2020 parliamentary elections in Bratislava, the political party did not reach the quorum and gained only $4.1 \%$. The highest support of $7.4 \%$ was achieved by the People's Party of our Slovakia in the Malacky district, where the number of vaccinated is the lowest within the Bratislava self-governing region (Statistical Office of the Slovak republic). 
Self-governing regions are the subject of political discussions after almost every regional election. Opponents of this level of self-government point to the limited competencies and high costs of their existence. According to them, the abolition of self-governing regions or the modification of the applied model would optimize the entire system of public administration in Slovakia. However, the coronavirus crisis brought new challenges and self-governing regions played an important role. In the article, we clearly declared it was the level of selfgoverning regions where the first measures against the spread of Covid-19 were taken. The decision of the authorities in the Bratislava self-governing region to interrupt teaching process at all secondary schools has become a positive example for the central power. Based on this decision, it was implemented universally in a short time. We also identified the decisions of selected self-governing units in the field of social matters or culture. In addition, they play an important role in vaccination because the state does not have sufficient space and personnel capacity to handle it. The establishment of vaccination centers by self-governing regions has significantly increased the pace of vaccination in total. Bratislava and Košice regions currently have centers with the largest capacity in Slovakia. Mobile vaccination centers are of great importance in the vaccination of marginalized groups as we can see in the example of the Košice self-governing region. However, the problem is the low rate of vaccination in selected districts of the Košice region. We have clearly identified the connection with the electoral gain of the political party Kotleba-Popular Party Our Slovakia, which refuses to be vaccinated in the long term. The higher the percentage won by the party in the parliamentary elections, the lower the percentage of people vaccinated.

\section{REFERENCES}

ADAMCOVÁ, M. 2011. Aktuálne prístupy ku štúdiu verejnej správy na Slovensku. In Cezhraničná spolupráca štátov V4. Sládkovičovo FVPaVS VŚS, pp. 188-204.

BRATISLAVA SECONDARY SCHOOL CLOSED OVER COVID-19 SUSPICION, 2020 [online] [2021-06-22] Available at $<$ https://spectator.sme. sk/c/22350514/bratislava-secondary-school-closed-over-covid-19-suspicion. html>

CSACHOVÁ, S. 2010. Štruktúra územnosprávneho členenia Slovenska. In Geografické poznatky bez hraníc. Košice: Univerzita Pavla Jozefa Šafárika v Košiciach, 2010. ISBN 078-80-7097-863-8. pp. 200-2013.

GURŇÁK, D. 2014. Regionálnogeografické špecifiká vývoja administratívneho 
členenia územia Slovenska. In Regionálne dimenzie Slovenska. Bratislava: Univerzita Komenského v Bratislave. ISBN 978-80-223-3725-0. pp 129-167. HAVLÍK, V. et al. 2020. The 2020 Parliamentary Elections in Slovakia: Steadily Turbulent Change of Direction. Czech Journal of Political Science. vol. 27, issue 3 pp. 221-234

KLIMOVSKÝ, D. 2014. Základy verejnej správy. 2.vyd. Bratislava: Wolters Kluwer, 2014. pp 455. ISBN 978-80-8168-002-1.

KONEČNÝ, V.-BRÍDZIKOVÁ, M-SENKO, Š. 2021. Impact of COVID-19 and Anti-Pandemic Measures on the Sustainability of Demand in Suburban Bus Transport. The Case of the Slovak Republic. Sustainability, vol. 13, issue 13. ISSN 2071-1050. pp. 2-29

KOVÁČOVÁ, E. 2015. Vývoj verejnej správy v podmienkach samostatnej Slovenskej republiky. In Acta FF ZČU. ISSN 1335-8081, 2015, vol. 7, no. 3, pp. 94-110.

KOVÁČOVÁ, E. 2014. Teória a prax verejnej správy v podmienkach Slovenskej republiky. Banská Bystrica: Belianum, 2014. s. 236. ISBN 978-80-557-07358.

MIKUŠ, D. Pohl'ady politických strán na verejnú správu. Trnava: UCM FSV, 2018. pp 118. ISBN 978-80-8105-962-9.

MACHYNIAK, J. 2018. Politické aspekty inštitiucionálizácie regionálnej samosprávy. In: Regionálna samospráva na Slovensku optikou verejnej politiky. Bratislava: IRIS, 2018. pp. 5-13. ISBN 978-80-8200-022-4

NIŽŇANSKÝ, V. - HAMALOVÁ, M. 2013. Decentralizácia a Slovensko. Trenčín: IAM Press, 2013. pp 82. ISBN 978-80-89600-18-2

SLOBODA, D. 2014. Kraje alebo župy? Piešt’any: Komunálne výskumní a poradenské centrum. 2014. pp 56

STATES OF EMERGENCY IN RESPONSE TO THE CORONAVIRUS CRISIS [online] [2021-06-22] Available at $<$ https://www.europarl.europa.eu/RegData letudes/BRIE/2020/652002/EPRS_BRI(2020)652002_EN.pdf $>$

STATISTICAL OFFICE OF THE SLOVAK REPUBLIC [online] [2021-06-23] Available at $<$ https://volby.statistics.sk/nrsr/nrsr2020/en/>

ŠVIKRUHA, M. 2018. Teoretické predpoklady existencie regionálnej samosprávy. In: Regionálna samospráva na Slovensku optikou verejnej politiky. Bratislava: IRIS, 2018. pp. 5-13. ISBN 978-80-8200-022-4

THE CLOSING ACCOUNT OF THE BRATISLAVA SELF-GOVERNING REGION [online] [2021-06-22] Available at $<$ https://bratislavskykraj.sk/ mdocs-posts/04-zaverecny-ucet-bsk-za-rok-2020/>

THE CLOSING ACCOUNT OF THE KOŠICE SELF-GOVERNING REGION [online] [2021-06-22] Available at < https://web.vucke.sk/files/sk/uradnatabula/financie/zaverecne-ucty-ksk/2020/tabulkove-prilohy-navrhuzaverecneho-uctu-ksk-za-rok-2020.pdf> 
Legislation

Act no. 221/1996 Coll. on the territorial and administrative organisation of the Slovak Republic Act no. 222/1996 Coll. on the organization of local state administration Act no. 302/2001 Coll. On the self-government of self-governing units Act no. 416/2001 Coll. on the transfer of certain powers from state administration bodies to municipalities and self-governing regions 